\title{
Use of a five-day progesterone-based timed artificial insemination protocol for dairy water buffaloes
}

\author{
Uso de um protocolo de inseminação artificial em tempo-fixo \\ baseado em cinco dias de exposição à progesterona em bubalinos \\ leiteiros
}

\author{
Luiz Francisco Machado Pfeifer ${ }^{1 *}$; Natália Ávila de Castro ${ }^{2}$
}

\begin{abstract}
The objective of this study was to determine the effect of a short five-day ( $5 \mathrm{~d})$ progesterone-based timed artificial insemination (TAI) protocol on the time of ovulation and fertility in dairy water buffaloes. In experiment 1, 30 dairy buffaloes were subjected to one of two estrous synchronization protocols. Females in the control group $(\mathrm{n}=17)$ were administered $2 \mathrm{mg}$ of estradiol benzoate (EB), and an intravaginal progesterone-releasing device (CIDR) was inserted on day -12 . On day -3 , CIDR inserts were removed and all cows were treated with $150 \mu \mathrm{g}$ of D-cloprostenol (a PGF2 $\alpha$-analogue). Fortyeight hours after CIDR removal, all cows received $100 \mu \mathrm{g}$ of gonadotropin-releasing hormone (GnRH). Females assigned to the short $5 \mathrm{~d}$ group $(\mathrm{n}=13)$ received treatment similar to the control group, except that the CIDR device was inserted on day -8 , and the EB treatment was eliminated. In experiment 2 , 51 dairy buffaloes were separated into control $(n=27)$ and short $5 \mathrm{~d}(\mathrm{n}=24)$ groups that received the same treatment as described for cows in experiment 1, except that all females were inseminated 16 to $18 \mathrm{~h}$ after $\mathrm{GnRH}$ injection. The use of a short $5 \mathrm{~d}$ progesterone-based TAI protocol with or without treatment with EB on day 0 did not affect the time of ovulation and pregnancy per artificial insemination in lactating water buffaloes. Thus, we suggest that the short $5 \mathrm{~d}$ TAI protocol may be successfully used as an alternative to induce ovulation in dairy buffaloes, with the particular advantages of avoiding EB treatment and a shorter interval from the beginning of the protocol to TAI.
\end{abstract}

Key words: Cows. Fertility. Ovulation.

\section{Resumo}

O objetivo deste estudo foi determinar o efeito de um protocolo de inseminação artificial em tempofixo (IATF) na taxa de ovulação e fertilidade em bubalinos leiteiros. No experimento 1, 30 búfalas leiteiras foram submetidas à um de dois protocolos sincronização de cio. As fêmeas do grupo Controle $(\mathrm{n}=17)$ receberam $2 \mathrm{mg}$ de benzoato de estradiol e um implante intravaginal de progesterona (CIDR) no Dia -12. No Dia -3, os implantes de CIDR foram removidos e todas as vacas foram tratadas com $150 \mu \mathrm{g}$ de D-Cloprostenol (análogo de PGF2 $\alpha$ ). Vinte e quatro horas após a remoção do CIDR, todas as vacas receberam $100 \mu \mathrm{g}$ de GnRH. As fêmeas do grupo $5 \mathrm{~d}(\mathrm{n}=13)$ receberam um CIDR no Dia $-8 \mathrm{e}$ o restante dos tratamentos foram similares ao Grupo Controle. No Experimento 2, 51 búfalas leiteiras foram separadas in grupo Controle $(n=27)$ ou $5 \mathrm{~d}(\mathrm{n}=24)$, que receberam os mesmos tratamentos descritos no Experimento 1, exceto pelo fato de as fêmeas terem sido inseminadas 16 a $18 \mathrm{~h}$ após a injeção de GnRH. O uso de um protocolo curto sem aplicação de benzoato de estradiol (BE) no dia

${ }^{1}$ Pesquisador A, Centro de Pesquisa Agroflorestal de Rondônia, Embrapa, RO, Porto Velho, RO, Brasil. E-mail: luiz.pfeifer@ embrapa.br

${ }^{2}$ Discente de Doutorado em Veterinária, Universidade Federal de Pelotas, UFPel, Pelotas, RS, Brasil. E-mail: nataliavetufpel@ gmail.com

* Author for correspondence 
0 não afetou o momento da ovulação e prenhez por inseminação artificial em búfalas leiteiras em lactação. Dessa forma, sugere-se que o protocolo curto de 5 dias pode ser usado como alternativa para induzir ovulação em bubalinos leiteiros, com a vantagem de não usar BE, além de permitir um menor intervalo entre o início do protocolo até a IATF.

Palavras-chave: Fertilidade. Ovulação. Vacas.

Water buffaloes play an important role in strengthening the agricultural economy and improving food security for the population of several Asian countries (YOUSUF et al., 2015) and some regions of South America, particularly in Northern Brazil. Despite their importance, the productivity of buffaloes remains negatively affected by certain reproductive features, including delayed puberty in heifers, poor estrus expression, long calving intervals, and breeding seasonality (SINGH et al., 2000). To overcome these limitations, hormonal treatments have been used to control ovarian function during the estrous cycle and optimize reproductive management.

For instance, estradiol/progesterone-based protocols have been widely applied for timed artificial insemination(TAI) of buffalo cows in South America (CARVALHO et al., 2014). Responses to these protocols, however, are inconsistent in terms of fertility. Moreover, the usual TAI protocols for buffaloes are of long duration (approximately $12 \mathrm{~d}$ ) in comparison to, for example, the classic Ovsynch protocol $(7 \mathrm{~d})$. This particular feature leads to an extended milk withdrawal period, which is required to avoid contamination of the milk with the estradiol ester used at the beginning of the protocol.

In addition to the long withdrawal period, the use of estradiol esters in livestock is prohibited in several countries. Depending on the chemical formula and the pharmaceutical laboratory, an ester of estradiol may have a withdrawal period of up to 30 days for milk. Thus, the development of protocols that reduce the duration of the treatment with exogenous progesterone and limit the length of time taken for milk withdrawal due to the use of estradiol may increase the adoption of TAI by the dairy buffalo industry. The objective of this study, therefore, was to determine the effect on the time of ovulation and fertility of dairy buffaloes of a short $5 \mathrm{~d}$ TAI protocol, which reduces the length of the exposure to progesterone and avoids use of estradiol benzoate.

All animal procedures were approved by the Embrapa Ethics in the Use of Animals Committee (approval number F.02/2014). Experiments 1 and 2 were performed using the facilities at the Embrapa Rondônia Research Farm, located in Presidente Médici, RO, Brazil (11¹0'33”S, 6154'03”W).

In experiment 1, 30 lactating crossbred water buffaloes (Murrah X Mediterrâneo) were used. Cows weighed 450 to $700 \mathrm{~kg}$ and had a body condition score (BCS) ranging from 2.5 to 3.5 (scale 1 to 5; $1=$ emaciated, 5=obese). Animals were maintained in a pasture of Brachiaria brizantha with ad libitum access to a mineral mixture, salt, and water.

The TAI protocol and hormonal treatments are depicted in Figure 1. Briefly, females in the control group $(n=17)$ were given an intramuscular (i.m.) injection of $2 \mathrm{mg}$ of estradiol benzoate (EB; Bioestrogen ${ }^{\circledR}$, Biogénesis-Bagó, Curitiba, Brazil) and received an intravaginal progesteronereleasing device (1.9 g progesterone, CIDR $^{\circledR}$; Pfizer Animal Health, São Paulo, Brazil) on day -12 to synchronize follicular wave emergence. On day -3 , CIDR inserts were removed and all cows were treated i.m. with $150 \mu \mathrm{g}$ of D-Cloprostenol (PGF2 $\alpha$ analogue; Croniben ${ }^{\circledR}$, Biogénesis-Bagó, Curitiba, Brazil). Forty-eight hours after CIDR removal, all cows were administered $100 \mu \mathrm{g}$ of Gonadotropinreleasing hormone i.m. (GnRH; Gestran plus ${ }^{\circledR}$, Tecnopec, Buenos Aires, Argentina). Females assigned to the short $5 \mathrm{~d}$ group $(\mathrm{n}=13)$ were treated similarly to the control group except for receiving a CIDR device on day -8 instead of day -12 , and 
the EB treatment was eliminated. The status of the ovulatory follicle was followed by ultrasonography
(SIUI CTS-900; equipped with a $5 \mathrm{MHz}$ linear-array transducer, Guangdong, China) at $12 \mathrm{~h}$ intervals from CIDR removal until ovulation was detected.

Figure 1. Experimental design used for dairy buffaloes treated with a progesterone insert for $9 \mathrm{~d}$ (control) or for 5 d (short 5-day group) of a TAI protocol. Abbreviations are as follows: CIDR, intravaginal progesterone device; EB, estradiol benzoate; PGF, prostaglandin F2 $\alpha$; TAI, timed artificial insemination; US*, ultrasonic examinations.

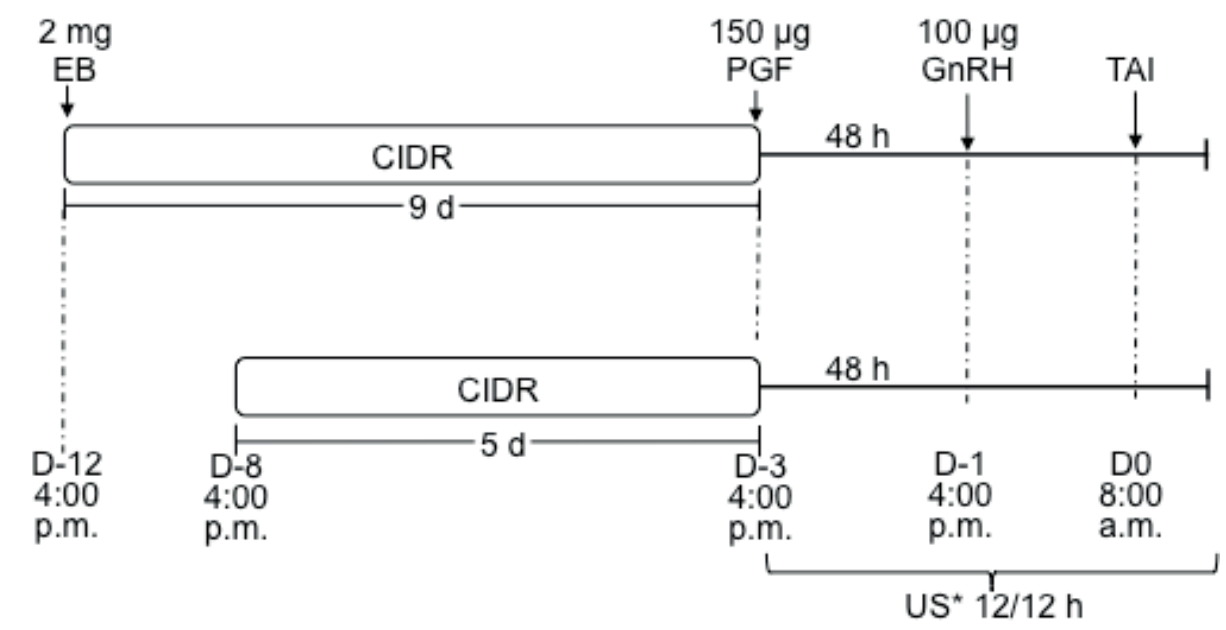

In experiment 2, 51 lactating crossbred buffaloes (Murrah X Mediterrâneo) were used. Cows weighed 410 to $725 \mathrm{~kg}$ and had a BCS ranging from 2.5 to 3.5. Animals were maintained on a pasture of Brachiaria brizantha with ad libitum access to mineral mixture, salt, and water. Females in the control $(n=27)$ and short $5 d(n=24)$ groups received the same treatment as described for cows in experiment 1 , except that all females were inseminated 16 to $18 \mathrm{~h}$ after $\mathrm{GnRH}$ injection (Figure 1). Ultrasonographic examinations were performed 35 days post-TAI to assess pregnancy status. Visualization of the embryonic vesicle and detection of the embryo with a heart-beat were the positive criteria for determining pregnancy.

All statistical analyses were performed using the SAS 9.0 software (SAS Institute Inc., Cary, NC, USA). Single-point outcome variables such as moment of ovulation after CIDR removal and diameter of the ovulatory follicle were analyzed using one-way analysis of variance. Differences of means among groups were determined using the Tukey's post hoc test. Proportions and binomial variables such as ovulation and pregnancy rates were analyzed using the Chi-square test. The ovulation rate was calculated as the number of cows that ovulated divided by the total number of treated cows. Similarly, pregnancy rate (P/AI) was calculated as the number of pregnant cows 30 days after TAI relative to the number of cows that were inseminated. Differences among groups were considered statistically significant if the P-value was $\leq 0.05$.

Reduction of the length of progesterone treatment along with the removal of EB from the TAI protocol did not affect ovarian responses and $\mathrm{P} / \mathrm{AI}$ in buffaloes (Table 1). In addition, the interval from CIDR removal to ovulation did not differ between the groups (Table 1). The ranges of time of ovulation after CIDR removal were 78 to 102 $\mathrm{h}$ and 78 to $90 \mathrm{~h}$ for control and short $5 \mathrm{~d}$ groups, 
respectively. One cow from each group failed to ovulate within this time frame.

The potential benefits of a reduction in the duration of TAI protocols has been extensively studied in dairy cows (GARCIA-ISPIERTO; LOPEZ-GATIUS, 2014; LIMA et al., 2013). Previous studies have shown the effectiveness of short protocols that use a GnRH treatment at the day of insertion of the progesterone device (BRIDGES et al., 2008; SANTOS et al., 2010). Nevertheless, to our knowledge, this is the first report evaluating the efficiency of a short $5 \mathrm{~d}$ TAI protocol in buffaloes that have not been administered GnRH or EB at the beginning of the protocol.

Table 1. Fertility responses of dairy water buffaloes treated with a conventional 9-day (control) or a short 5-day TAI protocol.

\begin{tabular}{lccc}
\hline & \multicolumn{2}{c}{ Treatment } \\
\cline { 2 - 4 } & Control & Short 5-day & P-value \\
\hline Ovulatory follicle diameter, mm* & $12.9 \pm 0.5$ & $13.1 \pm 0.6$ & 0.81 \\
Time of ovulation after CIDR removal, $\mathrm{h}^{*}$ & $77.2 \pm 1.7$ & $77.0 \pm 2.0$ & 0.93 \\
Proportion of ovulating cows, \%* & $94.1(16 / 17)$ & $92.3(12 / 13)$ & 0.84 \\
Pregnancy per AI, \%** & $37(10 / 27)$ & $37.5(9 / 24)$ & 0.97 \\
\hline
\end{tabular}

Data are presented as average \pm standard error

*Data from experiment 1

**Data from experiment 2 .

We observed a $\mathrm{P} / \mathrm{AI}$ of $37 \%$ in females synchronized with the short $5 \mathrm{~d}$ protocol, which was not different from the P/AI of control buffaloes synchronized by a conventional TAI protocol. Dairy cows treated with a $5 \mathrm{~d}$ progesterone-based TAI protocol without additional treatments on day 0 (EB or GnRH) had a P/AI somewhat similar to our results in buffaloes (31.6\%) (GARCIA-ISPIERTO; LOPEZ-GATIUS, 2014). Recently, a study that did not use EB at the beginning of a $7 \mathrm{~d}$ protocol, but still used GnRH $36 \mathrm{~h}$ after CIDR removal, achieved a $\mathrm{P} / \mathrm{AI}$ of $\sim 40 \%$ in buffaloes (HAIDER et al., 2015). These previous results are similar to the P/AI observed in the current study using a $5 \mathrm{~d}$ progesterone-based protocol.

Earlier studies demonstrated that pregnancy rates were higher after two inseminations (60\%) (NASEER et al., 2011), but not satisfactory with a single insemination (27\%) (MURUGAVEL et al., 2009), in buffaloes treated using a CIDR-GnRH protocol. In contrast, buffalo cows in seasonal anestrous synchronized with a conventional protocol consisting of $9 \mathrm{~d}$ of progesterone exposure along with an equine chorionic gonadotrophin (eCG) injection at CIDR removal achieved a P/AI of approximately 50\% (CARVALHO et al., 2014). As observed, the fertility of TAI dairy buffaloes is variable and further studies are still required to confirm whether a short $5 \mathrm{~d}$ protocol could successfully replace the conventional $9 \mathrm{~d}$ protocol as a less expensive alternative.

A routinely used method to minimize costs in TAI programs is to re-use the intravaginal progesterone inserts. In that regard, the use of short protocols in commercial buffalo herds may reduce the costs of the TAI protocol per cow, considering that the intravaginal progesterone device would be re-used more times in comparison with the $9 \mathrm{~d}$ conventional protocol. Moreover, our results indicate that the short $5 \mathrm{~d}$ TAI protocol may succesfully eliminate the need for EB treatment on day 0, which would also be cost-effective for farmers. The withdrawal of EB from the TAI protocol would permit the use of the short $5 \mathrm{~d}$ protocol in countries in which the use of estradiol esters is forbidden, such as the European Union (2008/97/CE, 2008). Since 2008, 
the use of estradiol-17 $\beta$ has been banned in farm animals by the European community because of its potential role as a complete carcinogen, as described by the Committee on Veterinary Measures Relating Science to Public Health.

In conclusion, the use of a short $5 \mathrm{~d}$ TAI protocol did not negatively affect ovarian responses and $\mathrm{P} /$ AI in dairy buffaloes, compared to the conventional $9 \mathrm{~d}$ protocol. Thus, short $5 \mathrm{~d}$ progesterone-based protocols could be a viable alternative to reduce costs of TAI and expand its use in buffaloes.

\section{Author contributions}

LFMP designed the study. LFMP and NAC performed the study, analyzed data, and wrote the manuscript. Both authors contributed equally.

\section{Acknowledgments}

Authors are grateful to Cícero Mendes, Paulo Marcos N. Araújo, and Jamyle Pereira Cestaro for their help with data collection and herd management during the experimental period. This research was supported by Embrapa (MP2 Project; InovaIATF 02.10.01.021.00.00 and MP1/PC3 Project 01.03.14.011.00.00). NAC was supported by CAPES from the Ministry of Education. Finally, we thank Dr. Luiz Gustavo B. Siqueira for kindly editing the manuscript.

\section{References}

BRIDGES, G. A.; HELSER, L. A.; GRUM, D. E.; MUSSARD, M. L.; GASSER, C. L.; DAY, M. L. Decreasing the interval between GnRH and PGF2alpha from 7 to 5 days and lengthening proestrus increases timed-AI pregnancy rates in beef cows. Theriogenology, Stoneham, v. 69, n. 7, p. 843-851, 2008.

CARVALHO, N. A.; SOARES, J. G.; SOUZA, D. C.; VANNUCCI, F. S.; AMARAL, R.; MAIO, J. R.; SALES, J. N.; SA FILHO, M. F.; BARUSELLI, P. S. Different circulating progesterone concentrations during synchronization of ovulation protocol did not affect ovarian follicular and pregnancy responses in seasonal anestrous buffalo cows. Theriogenology, Stoneham, v. 81, n. 3, p. 490-495, 2014.

EUROPEAN COMMUNITY 2008/97/EC, C. D. Official Journal European Community; Bruxelas, L318/9, p. 8-36, 2008.

GARCIA-ISPIERTO, I.; LOPEZ-GATIUS, F. Effects of different five-day progesterone-based fixed-time AI protocols on follicular/luteal dynamics and fertility in dairy cows. Journal of Reproduction and Development, Tokyo, v. 60, n. 6, p. 426-432, 2014.

HAIDER, M. S.; HASSAN, M.; KHAN, A. S.; HUSNAIN, A.; BILAL, M.; PURSLEY, J. R.; AHMAD, $\mathrm{N}$. Effect of timing of insemination after CIDR removal with or without GnRH on pregnancy rates in Nili-Ravi buffalo. Animal Reproduction Science, Manchester, v. 163, p. 24-29, 2015.

LIMA, F. S.; RIBEIRO, E. S.; BISINOTTO, R. S.; GRECO, L. F.; MARTINEZ, N.; AMSTALDEN, M.; THATCHER, W. W.; SANTOS, J. E. Hormonal manipulations in the 5-day timed artificial insemination protocol to optimize estrous cycle synchrony and fertility in dairy heifers. Journal of Dairy Science, Champaign, v. 96, n. 11, p. 7054-7065, 2013.

MURUGAVEL, K.; ANTOINE, D.; RAJU, M. S.; LOPEZ-GATIUS, F. The effect of addition of equine chorionic gonadotropin to a progesterone-based estrous synchronization protocol in buffaloes (Bubalus bubalis) under tropical conditions. Theriogenology, Stoneham, v. 71, n. 7, p. 1120-1126, 2009.

NASEER, Z.; AHMAD, E.; SINGH, J.; AHMAD, N. Fertility following CIDR based synchronization regimens in anoestrous Nili-Ravi buffaloes. Reproduction in Domestic Animals, Berlin, v. 46, n. 5, p. 814-817, 2011.

SANTOS, J. E.; NARCISO, C. D.; RIVERA, F.; THATCHER, W. W.; CHEBEL, R. C. Effect of reducing the period of follicle dominance in a timed artificial insemination protocol on reproduction of dairy cows. Journal of Dairy Science, Champaign, v. 93, n. 7, p. 2976-2988, 2010.

SINGH, J.; NANDA, A. S.; ADAMS, G. P. The reproductive pattern and efficiency of female buffaloes. Animal Reproduction Science, Manchester, v. 60-61, p. 593-604, 2000.

YOUSUF, M. R.; MARTINS, J. P.; HUSNAIN, A.; RIAZ, U.; RIAZ, H.; SATTAR, A.; JAVED, K.; AHMAD, N. Effect of oestradiol benzoate on oestrus intensity and pregnancy rate in CIDR treated anoestrus nulliparous and multiparous buffalo. Animal Reproduction Science, Manchester, v. 159, p. 104-108, 2015. 
